DOI https://doi.org/10.36059/978-966-397-194-0/1-22

\title{
STYLISTIC BASIS OF STEPHEN KING'S HORROR NOVELS
}

\section{Liubov Didukh}

\section{INTRODUCTION}

Stephen King is a popular modern writer of horror. Some critics do not approve his writing style, and this is what differentiates him from other popular horror writers. S. King's writing style is very specific and distinctive. The author uses many figures or measures that are not common to most modern writers and this is what makes him and his works so special. This article is focused on stylistic peculiarities of S. King's writing style. As Teodoro Gómez wrote in his book about S. King, 'King was manifoldly christened an American Dickens because of his style, plain and simple in receival ${ }^{, 1}$ [translation mine]. This cannot be argued - his writing style goes down well with most of his readers, although some of the more demanding intellectuals disdain it. Obviously, in the literary community there is controversy on this topic. Some people notice that 'it is very easy to be upset with horror writer Stephen King, for not only has he turned out his annual, successful terrifier, he has also produced a remarkable nonfiction work in which he discusses the meaning and the appeal of the horror story,2. This is not a popular technique among writers - to give away their secrets about how to write to achieve success. Nonetheless, this is just what S. King does. This is a reason of adoration from one side, but also a reason of animosity from the other. Of course, other popular readers do not want everyone to know how to be a good writer - this would cause a huge increase in literary competitors. Thanks to S. King's explanations it is easier for the readers to understand the roots of their fears. It is understandable then, that $\mathrm{S}$. King is more often adored by readers than other writers, although many writers really respect his achievements and talent. Being a best-selling author of horror stories in the world is undisputable. 'But the respect of the literary establishment has always eluded King. For years, the question

${ }^{1}$ Gómez, T., 2008. Człowiek i twórca: Stephen King, trans. M. Mróz. Warsaw, MUZA SA). P. 9.

2 Greeley, A. M., 1986. Stephen King's Horror Has a Healing Power [in:] Miller C. \& Underwood T. (ed.), Kingdom of Fear: The World of Stephen King (P. 19). Falmouth, Hodder \& Stoughton. 
of whether he was a serious writer was answered by a quick tabulation of book sales, film deals, income and sheer volume of output, which added up to a resounding "no". Commercial triumph did not equal literary value. Being a best seller was anathema"3. This fragment of the BBC article shows that S. King's popularity and the perception of his figure as a serious writer are not equal. Various people have been asked a question about whether S. King is a serious writer or not. Some of the answers are quoted in the analysed article. For example, Harold Bloom, the legendary critic said: 'I've described King in the past as a writer of penny dreadfuls, but perhaps even that is too kind. He shares nothing with Edgar Allan Poe. What he is is an immensely inadequate writer on a sentence-by-sentence, paragraph-by-paragraph, book-by-book basis . . . Stephen King is beneath the notice of any serious reader who has experienced Proust, Joyce, Henry James, Faulkner and all the other masters of the novel ${ }^{4}$. If compared to such great artists as Proust or Poe, S. King truly is not similar to them. According to some readers, this is his main advantage. According to many critics, his biggest disadvantage. All of this is attributable to his specific writing style.

The material of the research consists of different works written by S. King: The Shining, It, Carrie. And analysing stylistic features of three of the most popular novels written by the master of horror the article presents how distinctive S. King's style is, what impact it has on the reader and why did the writer decide to use such stylistic measures to achieve his goal.

\section{Genre nature of horror fiction on the basis of Stephen King's works}

Style is a writer's identification mark. It makes him special, different, unique. At least this is definitely what can be said about S. King's writing style. Both his fans and his critics would agree that the master of horror has a style that does distinguish itself.

$\mathrm{S}$. King is aware of the fact that many people recognize his style as very simple and casual. 'He writes in what E.B. White once called the "plain style" - what King himself has termed "the literary equivalent of a Big Mac and a large fries from McDonald's." This seemingly offhand,

${ }^{3}$ Ciabattari, J., 2014. Is Stephen King a Great Writer? Retrieved March 13, 2019, from www.bbc.com.

${ }^{4}$ Ciabattari, J., 2014. Is Stephen King a Great Writer? Retrieved March 13, 2019, from www.bbc.com. 
conversational style, when combined with his appealing characters, produces an almost immediate intimacy with the reader, ${ }^{5}$. This dictum shows S. King's approach to his 'plain style'. He understands that readers like simple sentences, just like they love Big Mac and fries although they are very common. Obviously, according to the writer, 'common' does not mean 'bad'.

Most of the great, known writers like Shakespeare tried to use solemn, ornate language. Children at schools now analyse their works and learn about writers' great art. Of course, humanity needs writers like that. Nevertheless, a book has also something more to offer the reader. It is supposed to be a pastime, to make a person relax after a long day with a cup of tea and a really good story written by some talented writer. This is exactly what S. King can do. He has been compared by D.E. Winter to a boatman. His goal is to ferry people from one bank to another, from the beginning of a story to the end of it. He is supposed to do it smoothly and rivetingly. 'In the horror fiction of Stephen King, we can embark upon the night journey, make the descent down the dark hole, cross the narrowing Reach [the name of the river from one of King's stories - M.T.], and return again in safety to the surface - to the near shore of the river of death. For our boatman has a master's hand' ${ }^{6}$. Even though King's style is not very sophisticated, it is good enough to engage the reader in a masterful way. Many readers appreciated this ability and loved his novels truly.

According to S. King, there are two simple statements about writing. The first one is: 'good writing bargains on mastering the basis (vocabulary, grammar, elements of style), [translation mine]. The second rule says: 'although you cannot make a bad writer become a professional writer, and although it is impossible to create a genius out of a good writer, you can, if you put enough effort, hard work and commitment in it, lift a professional to the level of the good author ${ }^{8}$ [translation mine]. This quotation shows us King's approach to the activity which is writing. The

${ }^{5}$ Winter, D. E., 1989. The Art. Of Darkness: The Life and Fiction of the Master of the Macabre: Stephen King. London, Hodder \& Stoughton. p. 34.

${ }^{6}$ Winter, D. E., 1989. The Art. Of Darkness: The Life and Fiction of the Master of the Macabre: Stephen King. London, Hodder \& Stoughton, p. 162. S-ka. p. 112.

${ }^{7}$ King, S., 2001. Jak pisać: Pamiętnik rzemieślnika. Warsaw, Prószyński i S-ka p. 112.

${ }^{8}$ King, S., 2001. Jak pisać: Pamiętnik rzemieślnika. Warsaw, Prószyński i 
author understands that a bad writer will never become a genius, but the point is to work on his writing. Even such a popular writer as S. King can always improve his style, find a new way of expressing his thoughts and ideas. The only thing he needs to do is try and not give up.

Discussing the stylistic features of S. King's works, many factors should be taken into consideration. One of them is writing rhythm. This is how the author talks about it: 'I'm not very concerned with style, but I am concerned with the balance. Language should have a balance the reader can feel and get into - rhythm to the language as it moves along. Because if the reader is seduced in the story, then it carries him away'. Most people connect rhythm with music, but it turns out that books also can, and should, have a rhythm. The basis of this field is narration. When the narration is good, readers cannot simply postpone reading the next chapter. They want to know what happens next, they are so much into the plot that they do not even realise how much the story implicated them. Another writer, Michael McDowell, admitted that he is jealous about how King can create such an effective narration. 'It has become increasingly apparent to me that books rise or fall by the rhythm of the narrative. A story can carry you along - despite lapses in grammar, probability, or tone - if the rhythm is right ${ }^{10}$ - he wrote.

This rhythm can be easily noticed in King's works. The descriptions are never too long - just enough to give all the important information. 'And the climaxes are exactly right. The dynamite is laid, stick by stick, and every one of them goes off, in a precise, rhythmic pattern ${ }^{, 11}$. Every S. King's novel is perfectly rhythmic - not too long (even though It can be even 1300 pages long) and not too short, because when one reads it, he does not feel like the story is dragging or like there is too few information. The plot is irrepressible and gripping, all of this thanks to King's narration.

${ }^{9}$ McDowell, M., 1986. The Unexpected and the Inevitable [in:] Miller C. \& Underwood T. (ed.), Kingdom of Fear: The World of Stephen King (p. 81). Falmouth, Hodder \& Stoughton.

${ }^{10}$ McDowell, M., 1986. The Unexpected and the Inevitable [in:] Miller C. \& Underwood T. (ed.), Kingdom of Fear: The World of Stephen King (p. 81). Falmouth, Hodder \& Stoughton, p. 84.

${ }^{11}$ McDowell, M., 1986. The Unexpected and the Inevitable [in:] Miller C. \& Underwood T. (ed.), Kingdom of Fear: The World of Stephen King (p. 81). Falmouth, Hodder \& Stoughton. 
Apart from narration, S. King states that stories consist of two more factors. One of them are descriptions, the second one - dialogues ${ }^{12}$. Description is very important, because it allows the reader participate in the story. According to the master of horror, making good descriptions is a thing to learn. At first, it should have proper length. 'Too meagre description makes the reader feel bewildered and lost. Too detailed one buries him under a stack of pictures and details. The trick is to find the golden mean ${ }^{, 13}$ [translation mine]. The truth is - it is easy to send the reader to sleep with too long description. It is difficult to make him go for the story again after that. This is also an element of the right rhythm. To keep the right pace, the writer must be aware of what S. King wrote about descriptions. The author suggests to allow the readers to supply the image of his characters with faces, figures and clothes ${ }^{14}$. This would be impossible if he gave an exact description of a protagonist. When the reader's imagination starts working, he becomes the co-author of the story on the level of his mind. When we read that Carrie was a 'toad among the swans' and a 'clumsy, squat girl with pimples all over her neck, back and buttocks ${ }^{15}$ [translation mine], it is easy to imagine the rest - her hair, her face, her clothes and the way she moves. It is not necessary for S. King to enumerate every piece of her wardrobe. The reader gets the point - Carrie looked like a scapegoat.

S. King also argues that descriptions of characters should not include any clues about their personality. He also thinks that describing how intelligent were protagonist's blue eyes and how brashly his chin was upstretched proclaims that the author is lazy and uses poor techniques ${ }^{16}$. 'According to me, a good description usually consists of a few wellmatched details that symbolise anything else. In most cases, those details are the first ones that come to my mind. They will surely make a good beginning ${ }^{, 17}$ [translation mine]. This statement shows that it is difficult to

${ }^{12}$ King, S., 2001. Jak pisać: Pamiętnik rzemieślnika. Warsaw, Prószyński i S-ka. p. 129.

${ }^{13}$ King, S., 2001. Jak pisać: Pamiętnik rzemieślnika. Warsaw, Prószyński i S-ka, p. 138.

${ }^{14}$ King, S., 2001. Jak pisać: Pamiętnik rzemieślnika. Warsaw, Prószyński i S-ka. p. 138.

${ }^{15}$ King, S., 2013. Carrie, trans. D. Górska. Warsaw, Prószyński i S-ka. p. 10.

${ }^{16}$ King, S., 2001. Jak pisać: Pamiętnik rzemieślnika. Warsaw, Prószyński i S-ka. p. 139.

${ }^{17}$ King, S., 2001. Jak pisać: Pamiętnik rzemieślnika. Warsaw, Prószyński i S-ka. 
make a description that would be too meagre, it is much easier to make the one which is too overbearing. Fortunately, S. King's descriptions are always perfectly attuned.

What about his dialogues? S. King wrote that dialogue is the key factor that determines the personality of the character - only people's acts tell about them more than words . . . and one of the basic rules of good prose is never to talk about something you can show ${ }^{, 18}$ [translation mine]. When the dialogue is good, the reader will pick up on whether the character is intelligent or foolish, amusing or uptight. Great examples of S. King's dialogues can be found in It. One of them between Beverly and her dad shows the situation in their house:

" "Where's the bacon?"

"Gone, Daddy. We finished it yesterday."

"Cook me a hamburger."

"There's only a little bit of that left, $t$-"

"The paper rustled, then dropped. His blue stare fell on her like weight."

"What did you say?" he asked softly.

"I said right away, Daddy." "19.

Although in this short piece of text there is no mention of relationship between Bev and her dad, the reader can easily draw a lesson from this conversation. The author does not need to write that Bev was afraid of her father and had to fulfil all of his wishes - it is obvious.

Another extremely important factor of S. King's success as a writer is the way he creates his characters. Anyone who ever read any novel written by him probably remembers the protagonists very well - their way of thinking, their experience and their features. Although, as mentioned above, King allows the reader to imagine the character in his own way, his characters are never dull. They are always vividly presented, all of them have some important history that the reader can find out about while progressing with the plot. 'King's genius as a prose stylist is his portrayal of these characters in strikingly real, human terms. His works repeatedly dramatize the compelling human consequences of the possession of strange talents, by developing a sympathetic reader identification with the protagonist and then producing an intense conflict on both physical and

${ }^{18}$ King, S., 2001. Jak pisać: Pamiętnik rzemieślnika. Warsaw, Prószyński i S-ka, p. 143.

${ }^{19}$ King, S., 2011. It. London, Hodder \& Stoughton. pp. 482-483. 
emotional levels ${ }^{20}$. Starting with Carrie, through Jack Torrance in The Shining to Annie Wilkes in Misery, all of King's characters are remarkable. They leave a permanent trace in the reader's mind. However, the author admits that his characters are not so colourful from the very beginning. In On Writing he wrote that they are flat at the start, have no personal features. 'I never demand my characters doing what I want. Contrarily, I want them to do everything their own way. Sometimes the effect is what I expected, yet sometimes I get something I was completely not prepared for ${ }^{21}$ [translation mine]. S. King is a supporter of allowing the story take its own course in a way that might surprise him and that will surely surprise the reader. The author does not necessarily have to control everything. King wrote that for him what happens to his characters as the story develops depends only on what he is finding out about them, in other words, on how they foster themselves ${ }^{22}$. Although the author does not argue that this is the best way to create protagonists, this is how he works. This is one of King's secrets.

S. King's characters are chillingly real. This is an effect of the way of presenting them to the reader. In On Writing S. King gives an example of Annie Wilkes, the nurse from Misery who imprisoned Paul Sheldon, a famous writer. 'Annie Wilkes . . might seem to us a psychopath, but you need to understand, that in her opinion she is completely normal - in fact, she perceives herself as a heroine... If I manage for a while to show you the world in her eyes - I will make you understand her madness - then maybe I can make her a person you are going to pity or even start to identify with. Result? She will become to you more threatening than ever - because she will be so real ${ }^{, 23}$ [translation mine]. If S. King would tell his readers that Annie was a crusty, mean brimstone with the worst intent, she would make them feel only hate. However, when the reader sees that this is not her fault, that she really does not realize the weight of her actions, he starts to feel sorry for her. Feelings for Paul start to engage with feelings for Annie. The reader is torn inside, but also terrified,

${ }^{20}$ Winter, D. E., 1989. The Art. Of Darkness: The Life and Fiction of the Master of the Macabre: Stephen King. London, Hodder \& Stoughton. p. 93.

${ }^{21}$ King, S., 2001. Jak pisać: Pamiętnik rzemieślnika. Warsaw, Prószyński i S-ka. p. 130.

${ }^{22}$ King, S., 2001. Jak pisać: Pamiętnik rzemieślnika. Warsaw, Prószyński i S-ka, p. 151.

${ }^{23}$ King, S., 2001. Jak pisać: Pamiętnik rzemieślnika. Warsaw, Prószyński i S-ka, p. 152. 
because as he starts to understand the character, he realizes that this could be a real person, even his neighbour. This is why S. King's novels arouse emotions and involve readers in the action.

One more factor that makes S. King's writing style special is the language he is using. This is what most of the critics argue about, that the language used by King is too plain, too common to call him a good writer. Obviously, thousands of readers in the world think otherwise.

In the book entitled The Linguistics of Stephen King there are many types of language means specified. It's obvious, that we use different language when we are at home with family, and different when we are in the office or at work. Those varieties of language are called 'registers' or functional styles. 'Stephen King is a master of mixing in these different types of registers in order to create a . . . "defamiliarizing effect" . . . Hohne observes this effect in Stephen King's work: "a fine example of its [language's] slippery dual nature is Stephen King's writing, where there is a great deal of tension between the heteroglossic orality that is slang speech, which codifies a knowledge rejected by those in power, and monologic orality, which embodies that power". King's texts, then, contain both "official" and "unofficial" language 24 . As the master of horror, S. King can combine different stylistic genre peculiarities in order to achieve his goal. His simple language is used to form a kind of friendship between his readers and characters of his novels. Official language is used in order to introduce some serious scenes, the atmosphere of dignity. Both of these 'registers' create a complete picture of the situation for the recipient and allow him to feel like a part of the story. One more example of S. King's unofficial language can be found in It: 'But could Silver go? Could he? Christ! And it was a damned good thing he could. . . He had raced to beat the devil that day, oh yeah, for sure, don't you just know it ${ }^{25}$. Reading fragments like this one, a reader feels as if the narrator was his best friend and they were talking about something that really happened. Reading becomes a real pleasure, not a torment. The language is easy to understand and it has one more advantage: it speeds up the action.

Genre elements occurring in S. King's works are also an important clue on his specific style. As mentioned above, most of his novels can be certainly identified as horror novels with a strong

${ }^{24}$ Anderson, J.A., 2017. The Linguistics of Stephen King: Layered Language and Meaning in the Fiction. Jefferson, McFarland. pp. 193-194.

${ }^{25}$ King, S., 2011. It. London, Hodder \& Stoughton. pp. 482-483. 
psychological adjunct. Narrative, although having a perfect rhythm, is often enriched with the use of graphic means, such as brackets, italics and other elements used in order to show the deeper level of the plot. Rising action in King's novels usually stalls for most of the plot, so the climax occurs rather by the end of the story, which keeps the reader guessing until the end. The setting is another repeatable element of horror novels written by S. King, for the action usually takes place in a small town in America, usually in Maine. What is more, many of these towns are fictive and mentioned in more than one story. 'In stories like It, he borrows liberally from real places and landmarks, highways and scenery, even real street corners ${ }^{26}$. This type of setting introduces a special atmosphere from the beginning of the book. Repetitive patterns in King's works also consist of characters - usually there are some youngsters, a writer who wants to achieve success, a man with an alcohol problem and a woman who suffers from it.

Last but not least, it is not only important how S. King writes - it also matters what he writes about. For example, children or teenagers are very important in his works. 'His stories are songs of innocence and experience, juxtaposing childhood and adulthood - effectively completing the wheel whose turn began in childhood by reexperiencing those days from a mature perspective. . . This is a powerful motif; it may cause the reader to look to his or her life as well as that of the characters ${ }^{, 27}$. Horror is scary when it involves adults, but it is terrifying when children are involved. The fact that $\mathrm{S}$. King uses children as characters of many of his novels also allows the reader to understand their feelings ant take their point of view - everyone was a child.

However, the author also mentions another important topic. 'King holds that the most essential element of an effective horror story is love of characters: "You have got to love the people. That's the real paradox. There has to be love involved, because the more you love . . then that allows the horror to be possible. There is no horror without love and feeling . . ., because horror is the contrasting emotion to our understanding of all the things that are good and normal. Without a

${ }^{26}$ Romano, A., 2018. Stephen King Has Spent Half a Century Scaring Us, But His Legacy Is So Much More Than Horror. Retrieved April 4, 2019, from www.vox.com.

${ }^{27}$ Winter, D. E., 1989. The Art. Of Darkness: The Life and Fiction of the Master of the Macabre: Stephen King. London, Hodder \& Stoughton. P. 11. 
concept of normality, there is no horror ${ }^{28}$. Even though this is connected with the plot, not directly with the writing style, it has a huge impact on the credibility of the story. If the readers do not get involved in characters' feeling, then their life or death does not mean so much to them. Where there is love, emotions are highlighted, and they play a major role in every horror. Among others, this important motif was shown in The Shining. Although Jack Torrance has problems with alcohol and child abuse, in fact he can be a loving husband and father. A few fragments in the novel show strong feelings between Jack and his wife, Wendy. He has many flaws and did many bad things in his life, but 'despite his shortcomings indeed, in part because of them - Jack is intensely human, sympathetic, and forgivable 29 . While the novel shows this effective love of characters and this is its great asset, the movie based on it failed to show these emotions. If Jack Torrance is not introduced as a person who can forgive and understand, his character loses vividness and the story is not frightening enough.

Except love, there is one more emotion used in many S. King's novels, also in The Shining - aggression. In his interview with D.E. Winter King admitted: 'I have always had tremendous feelings of aggression that it seemed necessary to cover up, to hide. And my writing has a clear channel for that - I think that this is why there is so much destruction in my early books, because it was a way of ridding myself of a lot of that energy that couldn't be drained in day-to-day life 30 . This is easy to notice - most of King's early novels have many scenes of destruction. His first published story, Carrie, ends with lots of blood, fire and death. Of course, horror is often associated with destruction, but it usually comes from supernatural creatures. S. King calls it down with people. His characters can be very aggressive and this is the most terrifying part for many readers, because it is incredibly realistic. We can hear every day how cruel people can be for another people, so S. King's characters are for us completely real.

${ }^{28}$ Winter, D. E., 1989. The Art. Of Darkness: The Life and Fiction of the Master of the Macabre: Stephen King. London, Hodder \& Stoughton, pp. 55-56.

${ }^{29}$ Winter, D. E., 1989. The Art. Of Darkness: The Life and Fiction of the Master of the Macabre: Stephen King. London, Hodder \& Stoughton. P. 56.

${ }^{30}$ Winter, D. E., 1989. The Art. Of Darkness: The Life and Fiction of the Master of the Macabre: Stephen King. London, Hodder \& Stoughton., p. 100. 
It was already mentioned that S. King's style is very distinctive. However, the author often admits that different horror writers were an inspiration for him.

In Danse Macabre S. King describes the day that probably was extremely important for his future career. He was 12 or 13 years old when he discovered an old box with his father's books. The author admits that the box was a real treasury of Avon paperbacks. Avon was then a publishing company which specialised in fantasy and horror literature. This discovery must have been really important to S. King, as he describes it with true affection. King continues: 'The pearl of the collection was H.P. Lovecraft's collection of short stories from year 1947 entitled The Lurking Fear' ${ }^{31}$ [translation mine]. He even remembers exactly the cover which is to him the best summary of Lovecraft's work. Although King admits that it was not his first meeting with horror, this collection was his first encounter with the genre's serious literature. 'This book, a gift from the father who left, allowed me for the first time to taste the reality beyond the minor movies displayed on Saturday afternoons 32 [translation mine]. These statements show how important role H.P. Lovecraft played in S. King's life. Further in Danse Macabre S. King admitted that Lovecraft opened a way for him, similarly as for Robert Bloch, Clark Ashton Smith, Ray Bradbury and others ${ }^{33}$. Although King's mother and aunt were opposed to this, his young brain was absorbing horror stories like a sponge. He started creating his own works very soon.

S. King admitted that it is normal to capture the writing style of the author that you read a lot. 'There is nothing bad about it. When, as a kid, I was reading Ray Bradbury, I was writing like Ray Bradbury everything was green, wonderful . . When I was reading James M. Cain, everything I wrote was brief, curt and tough as steel. When I was reading Lovecraft, my prose became decorative and baroque ${ }^{34}$ [translation mine]. This is normal when an author is fascinated with another artist's style. The difficulty lies in moulding an own characteristic way of writing. Further in the book King wrote: 'Stylistic repetition is a minor problem it is an entirely acceptable method of starting a writing career (and,

\footnotetext{
${ }^{31}$ King, S., 1995. Danse Macabre. Warsaw, Prószyński i S-ka. P. 145.

${ }^{32}$ King, S., 1995. Danse Macabre. Warsaw, Prószyński i S-ka.

${ }^{33}$ King, S., 1995. Danse Macabre. Warsaw, Prószyński i S-ka, p. 146.

${ }^{34}$ King, S., 2001. Jak pisać: Pamiętnik rzemieślnika. Warsaw, Prószyński i S-ka. p. 116.
} 
indeed, it cannot be dodged: every consecutive stage of a writer's work starts with some repetition), however, it is not possible to imitate another author's approach to the given genre ${ }^{35}$ [translation mine]. This approach is probably one of the most important elements in developing own writing style - every writer needs to feel his genre instead of trying to imitate what somebody else feels. This is why S. King gives an advice to those, who want to become good writers: 'Throw away Poe and Lovecraft before you start . . Both of these fine writers were rococo stylists, weaving words into almost Byzantine patterns . . . In spite of the antique charm both hold for modern readers, most editors regard the style as outdated and bankrupt ${ }^{36}$. Poe, Lovecraft and other horror writers can be a great inspiration, but their works should not become a form of a formula that can only be changed for some special purpose.

According to $\mathrm{T}$. Gómez, an author of a book that analyses S. King's works, in King's novels an influence of Poe, Lovecraft or Tolkien can be seen. However, while these other authors describe terrifying things with the words that hold the rank of art, S. King comes across as a normal guy, who tells an extraordinary story to his friend and engrosses him $^{37}$. This is probably the main feature that makes King's works different in the genre. This author is not trying to scale the heights of his artistic possibilities and give his horror stories a beautiful rim.

To compare S. King and H. P. Lovecraft, it is good to analyse the way both of these authors introduce blood into their stories. One of Lovecraft's short stories entitled The Picture in the House is only about 6 pages long, but conducting blood takes nearly one paragraph: 'The open book lay flat between us, with the picture staring repulsively upward. As the old man whispered the words "more the same" a tiny spattering impact was heard, and something shewed on the yellowed paper of the upturned volume. I thought of the rain and of a leaky roof, but rain is not red. On the butcher's shop of the Anzique cannibals a small red spattering glistened picturesquely, lending vividness to the horror of the engraving. The old man saw it, and stopped whispering even before my

${ }^{35}$ King, S., 2001. Jak pisać: Pamiętnik rzemieślnika. Warsaw, Prószyński i S-ka, p. 127.

${ }^{36}$ King, S., 1986. The Horror Writer and The Ten Bears. [in:] Miller C. \& Underwood T. (ed.), Kingdom of Fear: The World of Stephen King (p. 14). Falmouth, Hodder \& Stoughton.

37 Gómez, T., 2008. Człowiek i twórca: Stephen King, trans. M. Mróz. Warsaw, MUZA SA). p.p. 9-10. 
expression of horror made it necessary; saw it and glanced quickly toward the floor of the room he had left an hour before. I followed his glance, and beheld just above us on the loose plaster of the ancient ceiling a large irregular spot of wet crimson which seemed to spread even as I viewed $i t^{38}$. The fragment is very artistic indeed. While reading it, the reader can imagine the atmosphere in the room, can almost hear the first drop of blood falling on the paper and see how red it is. In comparison, S. King conducts blood in his stories very quickly. He did that already in his first published novel, Carrie: 'Suddenly, a fountain of red spouted from above. It spattered over the painting, there were streams of red on it. I knew immediately, even before it reached them, that it was blood ${ }^{39}$ [translation mine]. In this case, characters do not wonder whether it is blood, or maybe rain or paint. It does not start with a single drop. S. King hits his readers with action, with an unexpected and sudden event. The recipient does not even have time to predict what might happen. Once again, language is the greatest tool used by S. King to surprise his readers and to differentiate from other horror writers.

One more difference between King and his predecessors was given by Robert Bloch, another famous horror writer. He wrote: 'While . . Poe and Lovecraft came into full command of their fantasies they appeared to have an uncertain grasp upon realities; they had difficulty in dealing with everyday characters and situations. King, however wild his fancies, roots his work in the real world of today. His "normal" characters speak and think in the gritty language and slang idioms of the present generation ${ }^{, 40}$. This is another specific feature of S. King - his characters seem so normal that they could be our neighbours or even friends. The way they speak, how they behave is well known to readers. That ability to create such familiar characters probably emanates from being a good observer of the world that surrounds the author. Authors such as Poe or Lovecraft could not do this as well as S. King, and R. Bloch knew about it because he used to correspond with H.P. Lovecraft. 'All of the accounts say that Lovecraft was a terrible snob and, simultaneously, a very shy person (in addition, he was a $100 \%$ racist ...), a writer who corresponded a lot, but could not

${ }^{38}$ Lovecraft, H.P. The Picture in the House. Retrieved March 27, 2019, from http://www.hplovecraft.com/writings/texts/fiction/ph.aspx

${ }^{39}$ King, S., 2013. Carrie, trans. D. Górska. Warsaw, Prószyński i S-ka. p. 143.

${ }^{40}$ Bloch, R., 1986. Monsters in Our Midst [in:] Miller C. \& Underwood T. (ed.), Kingdom of Fear: The World of Stephen King (p. 25). Falmouth, Hodder \& Stoughton. 
deal with interpersonal relations. If he lived today, he would probably be a steady guest of online chats ${ }^{41}$ [translation mine]. This fragment of S. King's books shows that Lovecraft could not create real dialogues and reliable characters if he did not maintain contacts with other people. He lived in his imaginary world full of surrealistic creatures and figures.

A good example of Lovecraft's inability to create good dialogues is a fragment of his story entitled The Colour out of Space: 'Nothin'... nothin'... the colour... it burns... cold an' wet... but it burns... it lived in the well... I seen it... a kind o' smoke... jest like the flowers last spring... the well shone at night... Thad an' Mernie an' Zenas... everything alive... suckin' the life out of everything... in that stone... it must a' come in that stone . . ${ }^{42}$. Although S. King really respects Lovecraft for his work, he admitted that his genius in writing horror stories ended on dialogues. The fragment quoted above is an utterance of a moribund farmer and it drags on for more than 16 lines. People do not talk like this, even on their death bed. The dialogue lacks energy and life, it sounds dry and unnatural ${ }^{43}$. This is definitely a difference between Lovecraft and King. King's dialogues are always concrete and usually short, yet still interesting and giving the reader plenty of information about his characters.

The setting of S. King's stories is different too. Most horrors written by Poe or Lovecraft took place in Europe, in some magnificent buildings from the old times that gave the feeling of going back in time for the reader. King's novels are set in modern America, usually in a small town in Maine. Not all of towns mentioned by King even exist, many are just fiction. However, there is usually a small community in town which is placed far from a big city, so the atmosphere is getting tense very quickly.

What is more, S. King can implement optimism into his stories, even though they are terrifying. While H.P. Lovecraft's stories often embrace 'cosmic pessimism .. ., King's stories typically celebrate the existence of good ${ }^{44}$. In many of his novels a religious motif can be

${ }^{41}$ King, S., 2001. Jak pisać: Pamiętnik rzemieślnika. Warsaw, Prószyński i S-ka. p. 145.

${ }^{42}$ Lovecraft, H.P. The Collour out of Space. Retrieved March 27, 2019, from https://repositorio.ufsc.br

${ }^{43}$ King, S., 2001. Jak pisać: Pamiętnik rzemieślnika. Warsaw, Prószyński i S-ka. pp. 144-145.

${ }^{44}$ Winter, D. E., 1989. The Art. Of Darkness: The Life and Fiction of the Master of the Macabre: Stephen King. London, Hodder \& Stoughton, p. 110. 
noticed, most obviously in Carrie. Those mentions of God have a purpose - in every story it is different, but it is an important part of the plot. A mixture of horror and religion can seem strange, so not many horror writers have used it before. Nowadays, it can be noticed in many horror movies.

All in all, there are many distinctions between works written by S. King and by other horror writers. They are surely a result of the distinctive S. King's style discussed.

\section{Stylistic peculiarities of the horror novels Carrie, The Shining and It by Stephen King}

Genre peculiarities of the three discussed novels (Carrie, The Shining, It) show many similarities between S. King's works. However, each of his novels is different, has a special theme, matching characters and concerns different important motifs. Although S. King's style is easily recognizable for every horror reader, the author's style can also vary depending on the novel.

There are few important elements that make Carrie a piece of art in S. King's collection of horrors. At first, its main character is a young girl - a motif that occurs in many other novels written by the king of modern horror, where children or teenagers are hurt (e. g. Cujo) or are hurting somebody (e.g. Pet Sematary). It seems like nobody understands Carrie and nobody even tries to. However, Carrie turns out to be more than just a 'teenaged ugly duckling ${ }^{, 45}$ and she discovers her superpowers. The way Carrie is described is impressive. Even though, as it was already explained, S. King does not focus too much on giving detailed descriptions of his characters, readers can discover Carrie's appearance and personality while the action develops.

At the beginning of the story, the girl is presented as a klutz, hated by her peers, ignored by the teachers and abused by her mother. However, interludes in the text coming from the local newspapers or chronicles show the reader a different, unknown side of Carrie. For example, a note from an 'Enterprise' weekly said: 'On August 17 in Chamberlain, on Carlin Street, the rain of rocks appeared out of a clear blue sky. The fact was confirmed by many reliable people. The rocks fell mainly on Margaret White's house, seriously damaged the roof and destroyed two

45 Winter, D. E., 1989. The Art. Of Darkness: The Life and Fiction of the Master of the Macabre: Stephen King. London, Hodder \& Stoughton. p. 34. 
gutters and the drain worth about 25,000 dollars. Ms White is a widow and lives with her 3-year-old daughter, Carrietta ${ }^{\text {,4 }}$ [translation mine]. Following extracts confirm readers' suspicions that Carrie was responsible for all of the weird events described. Her character in the reader's imagination starts to gain more respect and slowly turns from a clumsy teenage girl to a powerful young woman.

One element that connects Carrie with The Shining - another King's popular novel - is featuring 'children of extraordinary psychokinetic abilities ${ }^{47}$. However, this time the horror does not come from the child. In The Shining almost all of the terror takes place in characters' imagination and subconsciousness, which is a novelty in the genre. M. Kruszelnicki directs the attention to a short fragment of this novel that tells us a lot about S. King's strategies: 'Blood-chilling gastness took his breath away. Yes. Yes. There was something, something terrifying, that the Overlook [name of the hotel - M.T.] saved for such an occasion. Maybe a huge spider buried under these withered leaves or a rat... or maybe corpse of some child who died here, in this playground. Did someone really die in here? Yes, perhaps. He was thinking about the woman in the bathtub. About the blood and the brain on the wall of the presidential suite. About a small child that fell off the ladder or the swing and with its skull fracted is crawling behind him in the dark, smiling, looking for his last companion in this timeless playground. He will hear it coming in a moment' (translation mine) ${ }^{48}$. In these few sentences the author used many techniques of scaring the reader. Child's imagination, darkness, claustrophobia, fear against spiders, rats and dead people - all of this is happening in just one small mind.

The Shining is also special for some other reasons. Firstly, the novel's main character, Jack Torrance, is a writer - one of S. King's favourite motifs. When the author describes Jack's efforts to write something successful it reminds the reader of King's writing cradle. The technique of describing characters is masterful also this time. Jack Torrance is presented in various ways depending on the person related to him. In the eyes of his son, Danny, Jack was a good father, sometimes getting angry without a serious reason, but he tried to fight his

${ }^{46}$ King, S., 2013. Carrie, trans. D. Górska. Warsaw, Prószyński i S-ka. P. 9.

47 Indick, B.P., 1986. King as a Writer for Children . [in:] Miller C. \& Underwood T. (ed.), Kingdom of Fear: The World of Stephen King (p. 201). Falmouth, Hodder \& Stoughton.

${ }^{48}$ King, S., 1998. The Shining. Warsaw, Prószyński i S-ka. Pp. 330-331. 
weaknesses. Danny did not want his mom to worry about dad. He could also read their thoughts. 'Daddy probably thought that they would have a better life if he had left. That the pain would stop. Daddy nearly always felt pain, mainly because of the Bad Thing. Danny could usually capture it: dad's permanent desire to hole up in a dark corner, look at the colour $T V$, eat peanuts and do the Bad Thing, until his thoughts calm down and stop torturing him' ${ }^{49}$ [translation mine]. Although Danny did not understand that 'the Bad Thing' was drinking, he knew that mom hated when dad was doing it. Wendy's point of view, however, was often changing. In the second chapter, she is so sad that she nearly cries: 'Jack and his pride! ${ }^{50}$ [translation mine]. Later, from Danny's thoughts it is obvious, that Wendy was thinking about the divorce. She truly hated Jack when he broke their son's arm. But in the sixth chapter we can read: 'Her man. She smiled dimly in the dark. . . The smile expressed both sadness and pleasure, for an expression "her man" evoked one hundred different feelings ${ }^{\text {,51 }}$ [translation mine]. This is the best example of Jack's ambiguity. His family loved him, feared him and hated him by turns. In Jack's own eyes, however, 'he always thought Jack Torrance is a really nice guy, who will have to learn how to moderate his anger one day ${ }^{, 52}$ [translation mine]. The reader's point of view on this particular character changes from chapter to chapter. Creating characters like this one is an interesting novelty in the field of horror stories and it is one of identification marks of S. King's writing style.

Another element that makes The Shining even more terrifying is the fact that evil can be inside of each of us. As S. King himself wrote in his book Danse Macabre, the main difference between the old and the new horror literature is connected with the characters' narcissistic personality; that monsters can not only appear on Maple Street, but they can also look out of our mirror at any moment ${ }^{53}$. This is exactly what is happening to Jack Torrance. The quintessence of the horror is the fact, that the hotel in which Jack and his family are staying is trying to change them, to turn them into different people. In the case of Jack, the head of the family, a husband and a father, it turns out to be a terrific change - to

${ }^{49}$ King, S., 1998. The Shining. Warsaw, Prószyński i S-ka. p. 37.

${ }^{50}$ King, S., 1998. The Shining. Warsaw, Prószyński i S-ka, p. 18.

${ }^{51}$ King, S., 1998. The Shining. Warsaw, Prószyński i S-ka, p. 56.

${ }^{52}$ King, S., 1998. The Shining. Warsaw, Prószyński i S-ka, p. 128.

${ }^{53}$ King, S., 2005. Danse Macabre, trans. P. Braiter, P. Ziemkiewicz. Warsaw, Prószyński i S-ka. p. 352. 
the extent of attempting to kill his family. This is how S. King is trying to show the worst part of a horror story - when love turns into bloodlust and the novel's character is completely defenceless against it.

One may wonder why S. King writes so much about children. An important reason is his view on child's thinking. 'King believes that it is important for the reader to cultivate the child's point of view . . You must have a child's ability to believe in everything ${ }^{54}$. This is why The Shining does not only show Danny's thinking. It also comes back to Jack's childhood, his relations with father and his memories that make him want to be a better father for Danny. It is a special measure making the reader feel like going back to being a kid, to thinking as a child. This stylistic feature connects all of the three novels discussed in this chapter. Carrie and The Shining were both featuring children or teenage characters. This is also an extremely important motif in another King's novel - It. Some readers claim that this is the best horror story written by modern master of horror. All of S. King's fears and obsessions reflect in this story ${ }^{55}$.

As already mentioned, in It $\mathrm{S}$. King offered his readers returning to childhood. Eleven-year-old children need to face the terrible clownmurderer. Human world order meshes up with the extra-terrestrial forces' order - the Good and the Evil. According to M. Kruszelnicki, it is not accidental that there is seven of children in this novel. 'Seven young emissaries of the Good bravely facing the terrifying avatars of the absolute Evil. How noncontingent is this number! Seven is the number of fullness and completeness consisting of the total of the lucky numbers: three (heavenly number) and four (earthly number) ${ }^{56}$ [translation mine].

Why did King choose children again to be his main characters? There are many fears that are common to kids, and that the adults do not believe in anymore. In this novel, greatest fears of childhood are real. A good example of such fear is shown in one of the scenes, when the boy is sitting on the bridge and moves his legs above the water: 'A hand closed around Eddie's foot . . . Urine spilled hotly down his legs and stained his jeans black in the moonlight. . . It was Dorsey. It was Dorsey as he had been buried. . . Eddieeee, his dead brother croaked, just like

${ }^{54}$ King, S., 2005. Danse Macabre, trans. P. Braiter, P. Ziemkiewicz. Warsaw, Prószyński i S-ka, p. 60.

${ }^{55}$ Gómez, T., 2008. Człowiek i twórca: Stephen King, trans. M. Mróz. Warsaw, MUZA SA). p. 102.

${ }^{56}$ Kruszelnicki, M., 2010. Oblicza strachu: Tradycja i wspótczesność horroru literackiego. Toruń, Wydawnictwo Adam Marszałek. P. 153. 
one of the dead people who were always coming back from the grave in the horror comics ${ }^{57}$. Every child is afraid of a cold hand coming from under the bed that will catch their leg at night. Adults know that it is a spoof, but if some unidentified thing touches their foot in the water, they often start to scream. King is aware of this fact - we grow out of our childhood fears, but many of them stay with us in a different form. "'The idea," he has said, "is to go back and confront your childhood, in a sense relive it if you can, so that you can be whole." We are haunted by our childhoods, by the important things we lost on the long walk to adulthood: the intensity of loves and fears, the talismanic rituals and objects of affection, and the moments of certain comprehension of our place in the scheme of things ${ }^{58}$. This special technique, a novelty in the genre in which mainly adults occur, has become an extremely important element of building his success as a writer. Adult readers go back to those beautiful times of being a kid, but they need to face their fears during this difficult but pleasant journey. 'The theme of IT was first expressed in King's short story The Boogeyman: "Maybe if you think of a thing long enough, and believe in it, it gets real. Maybe all the monsters we were scared of when we were kids, Frankenstein and Wolfman and Mummy, maybe they were real. Real enough to kill the kids who were supposed to have fallen into gravel pits or drowned in lakes or were just never found" "59. The author himself explained the idea: 'It's nothing but the Biblical idea that faith can move mountains and that faith proveth all things. So when this kid in IT believes that he is seeing the Mummy coming toward him across the ice of a frozen river, it really is the Mummy ${ }^{, 60}$. Children have greater faith than adults. It is easier for them to believe in monsters, ghosts and other creatures. However, this does not mean that King's books are for children. The characters of It come back to face the monster again as adults. The author is trying to show that faith is the key to horror stories: if the readers believe it could be true, it does not matter whether they are 8 or 68 . This stylistic feature is used in many of S. King's stories, and the motif of childhood is one of the author's favourite themes.

${ }^{57}$ King, S., 2011. It. London, Hodder \& Stoughton. P. 312.

58 Winter, D. E., 1989. The Art. Of Darkness: The Life and Fiction of the Master of the Macabre: Stephen King. London, Hodder \& Stoughton. P. 127.

59 Winter, D. E., 1989. The Art. Of Darkness: The Life and Fiction of the Master of the Macabre: Stephen King. London, Hodder \& Stoughton, p. 194.

${ }^{60}$ Winter, D.E., 1984. Interview with Stephen King. 


\section{CONCLUSIONS}

There are many factors that are important elements of S. King's writing style. Apart, they are nothing special, just some useful tips for people who want to become good writers. All together these elements create a unique, special style that represents the best horror writer in the modern world.

In his book On Writing King admitted that people who buy books usually do not care about the literary value of the novel. They do not really care about whether he is considered a great writer or just a writer whose style is nothing exceptional. What they care about is that his books can keep them intrigued and curious. 'People want an interesting story to take on a plane, something that will make them fascinated first, then implicate them and make them turn one page by another ${ }^{, 61}$ [translation mine]. His novels compete with TV and the Internet, and not many literary works can do that.

Examples from novels such as Carrie, The Shining and It were helpful in providing a stylistic analysis of S. King's way of writing. Several stylistic peculiarities that have become the author's identification mark have been analysed (S. King's way of introducing his personal beliefs, experience and fears into his fiction). S. King's novels and short stories contain multiple interesting themes, characters and symbols that tell us a lot about this popular author. Understanding his message hidden in many of his works is an important aim for literature and linguistics.

One thing that cannot be argued despite all of the good and bad opinions about King's writing is his standing out. A good summary on this field could be a fragment of The New Yorker article: 'There are lots of writers who tell it like it is, but only a few who, with such commitment and intensity, tell it like it isn't. King takes the weird and gives it weight. And yet, at the same time, his novels retain a lightness, a playfulness. They show us horrible things, but they also glow, I think, with King's joy - with his pleasure and exhilaration in imagining ${ }^{, 62}$.

\section{SUMMARY}

The article deals with the stylistic basis of Stephen King's horror novels. All in all, three of S. King's novels analysed above, as well as

\section{S-ka. P. 126.}

${ }^{61}$ King, S., 2001. Jak pisać: Pamiętnik rzemieślnika. Warsaw, Prószyński i

${ }^{62}$ Rothman, J., 2013. What Stephen King Isn't. Retrieved March 14, 2019 , from www.newyorker.com. 
many others, show many stylistic peculiarities of the author that are very interesting from the linguistic point of view. Many linguistic novelties in this field can be discovered. One of them is S. King's specific rhythm, strongly connected with narrative. Another one is related to the author's special ability of creating noteworthy characters and describing them. What is more, S. King's descriptions, dialogues, language and vocabulary all concur a specific style which is not common to other horror writers. Many repeatable themes of S. King's works also are a part of the writer's personal style, for many of them are strongly connected with his own life. The field of analysing S. King's writing style is very wide and many aspects can still be developed. One of these aspects is symbolism which will be studied in the following chapter.

\section{REFERENCES}

1. Anderson, J.A., 2017. The Linguistics of Stephen King: Layered Language and Meaning in the Fiction. Jefferson, McFarland.

2. Bloch, R., 1986. Monsters in Our Midst [in:] Miller C. \& Underwood T. (ed.), Kingdom of Fear: The World of Stephen King. Falmouth, Hodder \& Stoughton.

3. Ciabattari, J., 2014. Is Stephen King a Great Writer? Retrieved March 13, 2019, from www.bbc.com.

4. Gómez, T., 2008. Człowiek i twórca: Stephen King, trans. M. Mróz. Warsaw, MUZA SA)

5. Greeley, A. M., 1986. Stephen King's Horror Has a Healing Power [in:] Miller C. \& Underwood T. (ed.), Kingdom of Fear: The World of Stephen King (p. 19). Falmouth, Hodder \& Stoughton.

6. Indick, B.P., 1986. King as a Writer for Children. [in:] Miller C. \& Underwood T. (ed.), Kingdom of Fear: The World of Stephen King (p. 201). Falmouth, Hodder \& Stoughton.

7. King, S., 1986. The Horror Writer and The Ten Bears. [in:] Miller C. \& Underwood T. (ed.), Kingdom of Fear: The World of Stephen King. Falmouth, Hodder \& Stoughton.

8. King, S., 1995. Danse Macabre. Warsaw, Prószyński i S-ka

9. King, S., 1998. The Shining. Warsaw, Prószyński i S-ka

10. King, S., 2001. Jak pisać: Pamiętnik rzemieślnika. Warsaw, Prószyński i S-ka.

11. King, S., 2011. It. London, Hodder \& Stoughton.

12. King, S., 2011. It. London, Hodder \& Stoughton.

13. King, S., 2013. Carrie, trans. D. Górska. Warsaw, Prószyński i S-ka. 
14. King, S., 2013. Carrie, trans. D. Górska. Warsaw, Prószyński i S-ka.

15. Kruszelnicki, M., 2010. Oblicza strachu: Tradycja $i$ współczesność horroru literackiego. Toruń, Wydawnictwo Adam Marszałek.

16. Lovecraft, H.P. The Collour out of Space. Retrieved March 27, 2019, from https://repositorio.ufsc.br

17. Lovecraft, H.P. The Picture in the House. Retrieved March 27, 2019, from http://www.hplovecraft.com/writings/texts/fiction/ph.aspx

18. McDowell, M., 1986. The Unexpected and the Inevitable [in:] Miller C. \& Underwood T. (ed.), Kingdom of Fear: The World of Stephen King. Falmouth, Hodder \& Stoughton.

19. Romano, A., 2018. Stephen King Has Spent Half a Century Scaring Us, But His Legacy Is So Much More Than Horror. Retrieved April 4, 2019, from www.vox.com.

20. Rothman, J., 2013. What Stephen King Isn't. Retrieved March 14, 2019, from www.newyorker.com

21. Winter, D. E., 1989. The Art. Of Darkness: The Life and Fiction of the Master of the Macabre: Stephen King. London, Hodder \& Stoughton.

22. Winter, D.E., 1984. Interview with Stephen King.

\section{Information about the author: Liubov Didukh, $\mathrm{PhD}$,} Associate Professor at the Department of Foreign Languages and Translation Studies, Lviv State University of Life Safety 35, Kleparivska str., Lviv, 79007, Ukraine ORCID ID: https://orcid.org/0000-0001-8833-4571 